Соболь О.М., д.т.н., проф., НУЦЗУ, м. Харків, ORCID: 0000-0002-7133-6519,

Ляшевська О.І., к.н.держ.упр., дои., НУЦЗУ, м. Харків, ORCID: 0000-0002-1469-4141,

Бордюженко С.Я., к.т.н., НУЦЗУ, м. Харків, ОRCID: 0000-0001-6426-3473

Sobol O., Doctor in Technical Sciences, Professor, Professor of the Department of Management and organization in the field of civil protection, National University of Civil Defence of Ukraine, Kharkiv,

Liashevska O., PhD in Public Administration, Associate Professor, Associate Professor of the Department of Management and organization in the field of civil protection, National University of Civil Defence of Ukraine, Kharkiv,

Bordiuzhenko S., PhD in Engineering, Teacher-methodologist of the Department of Internal Quality Assurance of Education of the Educationalmethodical Center, National University of Civil Defence of Ukraine, Kharkiv

\title{
МЕХАНІЗМИ ОЦІНКИ РИЗИКІВ ВИНИКНЕННЯ ПОЖЕЖ
}

\section{MECHANISMS OF FIRE RISK ASSESSMENT}

Стаття присвячується дослідженню механізму оцінки ризиків виникнення пожеж та інших небезпечних подій. Проаналізовано складові механізму оцінки ризиків. Зазначено, що одним із основних елементів, що характеризує стан пожежної безпеки об'єкта господарювання, є ризик виникнення пожежі.

Ключові слова: державне управління, державне регулювання у сфері пожежної безпеки, ризик-орієнтований підхід, система оиінювання пожежної безпеки.

The article is devoted to the study of the mechanism of risk assessment of fires and other dangerous events. The components of the risk assessment mechanism are analyzed. It is noted that one of the main elements that characterizes the state of fire safety of the facility is the fire risk.

Key words: public administration, state regulation in the field of fire safety, riskoriented approach, fire safety assessment system.

Постановка проблеми. Для об'єктивної оцінки стану пожежної безпеки об'єкта господарювання необхідно застосовувати ризик-орієнтований підхід. Тому, перш за все, необхідно проводити аналіз статистичних даних щодо кількості пожеж у визначеній галузі або для певного типу об'єктів господарювання. Важливо також визначити і можливі наслідки від ймовірної пожежі.

Згідно статистичних даних в Україні існують сталі тенденції щодо збільшення пожеж та зростання збитків завданих ними. Аналіз статистичної 
інформації стосовно пожеж дає підстави стверджувати про недостатній рівень забезпечення пожежної безпеки в Україні.

Слід відзначити, що діяльність наглядових органів у сфері пожежної та техногенної безпеки має бути спрямованою, у тому числі, на зниження рівнів відповідних пожежних ризиків. Оптимізація наглядової діяльності дозволяє упорядкувати організаційно-управлінські функції через досягнення балансу між напрямами роботи. Наприклад, при зниженні кількості контрольних заходів більше уваги приділити інформаційній роботі, консультуванню або іншим формам профілактики, що мають велике значення з точки зору обізнаності суб'єктів господарювання вимогам діючого законодавства у сфері пожежної та техногенної безпеки. В цілому такий підхід сприяє зниженню фінансової складової у забезпеченні системи державного управління [3]. У зв'язку з цим, дослідження механізмів оцінки ризиків виникнення пожеж $\epsilon$ актуальним.

Аналіз останніх досліджень і публікацій. Теоретичні та методологічні основи державного управління у сфері цивільного захисту, його механізми, шляхи вирішення ключових питань реалізації політики у цій сфері досліджували вчені: С. Андреєв, М. Брушлинський, Ю. Воробйов, Ю. Глуховенко, В. Доманський, О. Могильниченко, М. Стеблюк, О. Труш, Г. Федулов, В. Федоренко, В. Шоботов, та ін. Водночас досліджень стосовно розробки та затвердження методик визначення ризиків, а також щодо впровадження ризик-орієнтованого підходу в сфері пожежної та техногенної безпеки, практично немає.

Постановка завдання. Метою статті $є$ визначення механізмів впровадження ризик-орієнтованого підходу в сфері пожежної та техногенної безпеки. Для досягнення мети статті необхідно вирішити наступні основні проблемні питання: 1. Розглянути питання щодо розробки та затвердження методик визначення зазначених ризиків. 2. Дослідити підходи стосовно нормування ризиків. 3. Визначити механізми управління ризиками.

Виклад основного матеріалу. Для запуску механізму оцінки ризиків виникнення пожеж та інших небезпечних подій необхідно вирішити наступні основні проблемні питання:

1. Розробка та затвердження методик визначення зазначених ризиків.

На теперішній час в Україні існує методика визначення ризиків та їх прийнятних рівнів для декларування безпеки об'єктів підвищеної небезпеки, яка затверджена наказом Міністерства праці та соціальної політики України від 04.12.2002 р. №637. Зазначена методика реалізує кількісну оцінку ризиків, причому ризик визначається як ступінь імовірності певної негативної події, яка може відбутися в певний час або за певних обставин на території об'єкта підвищеної небезпеки та/або за його межами.

Методика призначена:

- для розробки декларації безпеки об’єктів підвищеної небезпеки; 
- для прийняття рішень щодо розташування та експлуатації об'єктів підвищеної небезпеки;

- для розробки заходів щодо запобігання аварій та підготовки до реагування на них;

- для визначення обсягу відповідальності та страхових тарифів при страхуванні цивільної відповідальності суб'єктів господарської діяльності за шкоду, що може бути заподіяна аваріями на об'єктах підвищеної небезпеки відповідно до вимог Закону України “Про об’єкти підвищеної небезпеки” та Закону України "Про страхування".

Аналіз небезпеки й оцінка ризику виконується в повному обсязі, передбаченому цією методикою, для об'єктів підвищеної небезпеки першого класу. Для об'єктів підвищеної небезпеки другого класу визначаються тільки масштаби небезпеки відповідно до вимог п. 17 цієї Методики [2].

Методика може застосовуватися також для оцінки рівня ризику й експертизи рішень з безпеки потенційно небезпечних об'єктів, у тому числі під час:

- розробки нових технологій та конструювання обладнання;

- проектування та розташування нових виробництв;

- реконструкції діючих виробництв;

- експертизи діючих виробництв i тих, що реконструюються та проектуються;

- розробки планів локалізації та ліквідації аварій;

- організації страхового захисту майна підприємств;

- розгляду конфліктів між суб'єктом господарської діяльності, що експлуатує чи планує експлуатацію потенційно небезпечного об'єкту, та будь-якими зацікавленими сторонами, для яких аварії на об'єктах підвищеної небезпеки можуть мати негативні наслідки.

Методика призначена для фахівців у галузі промислової безпеки та охорони праці, керівників і фахівців підприємств, а також для фахівців органів виконавчої влади, що регулюють відносини в сфері діяльності об'єктів підвищеної небезпеки, відповідно до вимог Закону України “Про об'єкти підвищеної небезпеки”. Методика є основою для розробки відомчих або галузевих керівних документів 3 проведення аналізу ризику об'єктів підвищеної небезпеки відповідно до їх специфіки [2].

Розглядаються такі види ризиків, як індивідуальний, територіальний та соціальний. При визначенні ризиків враховуються ймовірності виникнення аварії (дерево відмов), ймовірність наслідків аварії (загибелі людей), ймовірність реалізації одного з можливих видів аварії (пожежі, вибуху, розсіювання шкідливих домішок та ін.). При визначенні індивідуального ризику враховується ймовірність появи людини у відповідній точці простору.

Разом з тим, ризик-орієнтований підхід має бути застосований не тільки до об’єктів підвищеної небезпеки, але й для інших суб'єктів господарю- 
вання, що потребує розробки відповідних методик, які мають враховувати особливості зазначених суб’єктів (наприклад, об'єкти з масовим перебуванням людей тощо). Більш того, зазначені методики можуть бути як кількісними, так і якісними, в яких застосовується експертне оцінювання.

Якщо розглянути закордонний досвід, то можна виділити такі методи оцінки ризиків:

- метод «Дау Кемікл» (США) - для хімічних підприємств;

- метод FSES (США) - для закладів охорони здоров'я;

- метод FRIM (Швеція);

- метод Гретенера (Швейцарія, Австрія, Португалія, Іспанія, Франція, Бельгія) - пожежний ризик $\mathrm{R} \epsilon$ мірою балансу між ймовірністю виникнення пожежі, потенційним збитком і захисними заходами;

- метод LOPA (міжнародний);

- метод Монте-Карло (міжнародний) та інші.

Більшість 3 наведених методів $\epsilon$ індексними i, як правило, оцінюють саме пожежну небезпеку.

Отже, вирішення питання щодо розробки та затвердження методик визначення ризиків $є$ одним 3 найважливіших кроків щодо впровадження ризик-орієнтованого підходу в сфері пожежної та техногенної безпеки.

2. Нормування ризиків.

Нормування ризиків виникнення надзвичайних ситуацій техногенного та природного характеру здійснюється Концепцією управління ризиками виникнення надзвичайних ситуацій техногенного та природного характеру, яка затверджена розпорядженням Кабінету Міністрів України від 22 січня 2014 p. № 37-p.

Реалізація Концепції дасть змогу:

- запровадити нові дієві форми аналізу, оцінки, експертизи і контролю безпеки потенційно небезпечних об'єктів на всіх етапах життєвого циклу;

- запровадити нормування рівнів ризиків та застосування відповідних норм під час удосконалення механізмів державного регулювання у сфері техногенної та природної безпеки;

- створити сприятливі умови для запровадження системи аналізу та управління ризиками як основи регулювання безпеки населення і територій України;

- прискорити формування єдиного підходу з управління безпекою в усіх сферах і галузях виробництва;

- забезпечити прозорість, відкритість і ефективність діяльності органів державної влади у сфері управління ризиками [4].

Разом з тим, до недоліків даної Концепції слід віднести відсутність визначення поняття «ризик», а також необгрунтованість гранично допустимого $\left(10^{-5}\right)$ та мінімального ризиків $\left(10^{-8}\right)$. Як обгрунтування в Концепції зазначено наступне: «Під час визначення рівнів прийнятних ризиків застосовуватимуться значення ризиків, щуо використовуються в економічно розвинутих 
державах». Також незрозумілими є одиниці вимірювання ризиків.

Ще однією спробою нормування ризиків є вищенаведений наказ Міністерства праці та соціальної політики України від 04.12.2002 p. №637, в якому зазначені неприйнятні та прийнятні рівні для індивідуального, територіального та соціального ризиків на об'єктах підвищеної небезпеки.

3 іншого боку, постановою Кабінету Міністрів України від 5 вересня 2018 року №715 затверджено критерії, за якими оцінюється ступінь ризику від провадження господарської діяльності та визначається періодичність здійснення планових заходів державного нагляду (контролю) у сфері техногенної та пожежної безпеки Державною службою з надзвичайних ситуацій. До зазначених критеріїв відносяться:

- вид об’єкта (приміщення, будівля, споруда, будинок, територія), що належить суб'єкту господарювання на праві власності, володіння, користування;

- площа об'єкта;

- максимальна розрахункова (проектна) кількість людей, які постійно або періодично перебувають на об'єкті;

- умовна висота об'єкта (висота, яка визначається різницею позначок найнижчого рівня проїзду (установлення) пожежних автодрабин (автопідйомників) і підлоги верхнього поверху без урахування верхніх технічних поверхів, якщо на технічних поверхах розміщено лише інженерні обладнання та комунікації будинку);

- наявність та масштаб небезпечних подій, надзвичайних ситуацій, які сталися на об'єкті протягом останніх п'яти років, що передують плановому періоду;

- клас наслідків (відповідальності) під час будівництва об'єкта;

- кількість порушень вимог законодавства у сфері техногенної та пожежної безпеки, пов'язаних з експлуатацією або під час будівництва об'єкта та виявлених протягом останніх п'яти років, що передують плановому періоду.

Аналіз вищенаведених критеріїв дозволяє зробити висновок, що зазначені критерії $є$ необгрунтованими, не враховується ймовірність виникнення небезпечної події, яка може змінюватись протягом часу, а також немає диференціації порушень вимог законодавства у сфері техногенної та пожежної безпеки (не аналізується значимість даних порушень), що може призвести до формального підходу щодо віднесення суб'єкта господарювання до відповідного ступеню ризику.

Віднесення суб'єкта господарювання до високого, середнього або незначного ступеня ризику здійснюється з урахуванням суми балів, нарахованих за всіма критеріями, за такою шкалою:

від 41 до 100 балів - високий;

від 21 до 40 балів - середній;

від 0 до 20 балів - незначний.

Якщо суб'єкту господарювання належить на праві власності, володіння або користування більше одного об’єкта, кількість балів нараховується за 
всіма критеріями, окремо щодо кожного об'єкта [5].

Тобто маємо колізію, коли з одного боку здійснюється нормування ризиків як ймовірностей, а з іншого - здійснюється оцінка та нормування ризиків у балах.

Таким чином, нормування ризиків, тобто встановлення гранично допустимих рівнів ризиків, має бути обгрунтованим і взаємопов'язаним із затвердженими методиками оцінки ризиків.

3. Управління ризиками.

У Концепції управління ризиками виникнення надзвичайних ситуацій техногенного та природного характеру зазначено, що основними механізмами державного регулювання у сфері управління ризиками $є$ державна стандартизація, сертифікація, державна експертиза, державний нагляд і контроль, ліцензування, економічне регулювання, декларування безпеки небезпечних об'єктів і страхування.

Особливості і ступінь впливу державного регулювання на конкретні об'єкти управління повинні визначатися з урахуванням значень їх реальних ризиків, а також здійснених заходів щодо мінімізації ризиків на всіх стадіях життєвого циклу небезпечних об'єктів (проектування, розміщення, будівництво, монтаж, пуск в експлуатацію, функціонування, ліквідація).

Основою державної системи управління у сфері техногенної та природної безпеки і відповідно управління ризиками повинні стати економічні механізми. Таким чином, до суб'єктів управління ризиками можна віднести:

- страхові компанії (обов'язкове страхування відповідальності);

- аудиторські компанії (незалежна оцінка ризиків);

- наглядові органи у сфері пожежної та техногенної безпеки (проведення аудиту безпеки разом 3 незалежними аудиторами);

- заклади вищої освіти та науково-дослідні установи ДСНС України (розробка методик визначення ризиків; підготовка експертів, що працюють на ринку аудиторських послуг);

- ДСНС України (надання акредитацій незалежним організаціям та експертам, що працюють на ринку аудиторських послуг; підтвердження компетенції цих організацій та їх фахівців).

У різних країнах під аудитом розуміються різні види контролю. В одних - це комплексне управління ризиками, кінцевою метою якого $\epsilon$ вироблення концепції безпеки підприємства, в той час як в інших - попередня страхова оцінка підприємства. При цьому форми проведення аудиту безпеки в різних країнах носять як добровільний, так і обов'язковий характер.

Наприклад у Німеччині участь незалежних аудиторів в області пожежної безпеки поряд з інспекторами пожежної профілактики в розгляді та узгодженні проектно-кошторисної документації на будівництво великих об'єктів є обов'язковим.

У Франції аудит безпеки здійснюється на двох етапах: в процесі будівельних робіт і безпосередньо під час експлуатації будівлі. 
Інакше кажучи, необхідно чітко визначити, який підхід до аудиту безпеки є найбільш прийнятним в Україні.

Висновки. Вирішення питання щодо розробки та затвердження методик визначення ризиків $є$ одним 3 найважливіших кроків щодо впровадження ризик-орієнтованого підходу в сфері пожежної та техногенної безпеки. Нормування ризиків, тобто встановлення гранично допустимих рівнів ризиків, має бути обгрунтованим і взаємопов'язаним із затвердженими методиками оцінки ризиків. Перспективою подальших розвідок даної проблематики $\epsilon$, на наш погляд, дослідження механізмів державного регулювання у сфері пожежної безпеки.

\section{Список використаних джерел:}

1. Наказ ДСНС від 22.03.2018 № 189 «Система оцінки ефективності державного нагляду (контролю) за додержанням і виконанням вимог законодавства у сфері цивільного захисту, пожежної та техногенної безпеки».

2. Наказ від 04.12.2002 N 637 Про затвердження Методики визначення ризиків та їх прийнятних рівнів для декларування безпеки об'єктів підвищеної небезпеки.

3. Международная финансовая корпорация (IFC), Управління ризиками в наглядовій діяльності: огляд, методологія і практика застосування. Режим доступу: http://www.ifc.org/europe/belarus.

4. Розпорядження КМУ від 22 січня 2014 р. № 37-р «Про схвалення Концепції управління ризиками виникнення надзвичайних ситуацій техногенного та природного характеру».

5. Постанова КМУ від 5 вересня 2018 р. № 715 Київ Про затвердження критеріїв, за якими оцінюється ступінь ризику від провадження господарської діяльності та визначається періодичність здійснення планових заходів державного нагляду (контролю) у сфері техногенної та пожежної безпеки Державною службою 3 надзвичайних ситуацій. Декларування безпеки об'єктів підвищеної небезпеки.

\section{References:}

1. Nakaz DSNS vid 22.03.2018 № 189 "System for assessing the effectiveness of state supervision (control) over compliance with and compliance with legislation in the field of civil protection, fire and man-made safety."

2. Nakaz vid 04.12.2002 N 637 «On approval of the Methodology for determining risks and their acceptable levels for declaring the safety of high-risk objects».

3. International Finance Corporation (IFC), Managing rizik in the look of the world: attention, methodology and practice, available at: http://www.ifc.org/europe/ belarus (Accessed 01 November 2018).

4. Rozporyadzhennya KMU vid 22 sichnya 2014 r. № 37-r "On approval of the Concept of risk management of emergencies of man-made and natural nature".

5. Postanova KMU vid 5 veresnya 2018 r. № 715 «Kyiv On approval of criteria for assessing the degree of risk from economic activity and determining the frequency of planned measures of state supervision (control) in the field of man-made and fire safety by the State Emergency Service. Declaration of safety of high-risk objects». 